\title{
Introduction to the Special Issue on the Intersection of Finances and Overall Well-Being
}

\author{
Megan McCoy ${ }^{1}$
}

Published online: 23 January 2020

๑) Springer Science+Business Media, LLC, part of Springer Nature 2020
We are pleased to bring you this special issue called "Exploring the Intersection of Finances and Overall WellBeing". The articles in this issue include an array of theoretical and research papers focused on exploring the role money plays in our lives and describes how systemic therapists can address finances in practice to improve clients' well-being. The goal of this special issue is to rejuvenate mental health practitioners' interest in the role finances play within our clinical practice. After all, it was a decade ago when Family Relations did a special issue called "Family, Finances, and Hard Times". In the guest editorial of the special issue, Dew (2010) decried the avoidance of finances by mental health professionals. Specifically, he said that he hoped that, "this special issue might become one of many watershed moments where the discipline of family studies recognizes how central financial issues are to families and to family functioning" (Dew 2010, p. 341). During the same period, the field of financial therapy was born (Grable et al. 2010). Financial Therapy was the marriage of systemic therapists and financial professionals to attend to the client(s)'s financial, emotional, psychological, behavioral, and relational (FTA, n.d.). These two events should have led to changes in marriage and family therapy training and practice. However, in a recent annotated bibliography on financial therapy, Glenn et al. (2020) found relatively few publications on finance's role within the field of marriage and family therapy. This special issue seeks to remedy this oversight by presenting some of the finest scholarship in the field of Financial Therapy.

Research has documented the negative impact money can have on individuals', couples', and families' functioning. We discovered that money is the number one stressor in Americans' lives (Klontz et al. 2008), money fights are qualitatively worse than other kinds of fights (Dew and Stewart 2012), financial stress is related to poor mental health

Megan McCoy

megan.mccoy.mft@gmail.com

1 Kansas State University, Manhattan, USA
(Selenko and Batinic 2011), and financial stress affects our physical health (Sweet et al. 2013). Financial stress can even negatively influence our ability to parent (Lee et al. 2011). Despite these discoveries, couple and family therapists still appear to be avoidant on entering into this topic area. Potentially, this avoidance could be due to our own financial health. Compared to other occupations, mental health professionals have significantly lower levels of financial health (Britt et al. 2015). We are more likely to hold money avoidant beliefs, including the belief that money is bad, rich people are greedy, or there is a virtue in living with less money (Klontz and Britt 2012). Mental health professionals' uneasiness about accepting fees from clients (e.g., Monger 1998). Marriage and family therapy programs rarely addressed personal finance, math, etc. (Klontz et al. 2008) "It has been argued that the mental health field as a whole has avoided addressing the topic of money in their own lives, as well as the lives of their clients" (Britt et al. 2015, p. 17). In order to fill the void in the mental health field, this special issue provides valuable insights into the different ways money plays out in the therapy room. The articles cover a wide range of topics from financial anxiety to financial infidelity, but each article's focus remains on how practitioners can aid their clients by understanding the connection between financial well-being and overall well-being.

First, Megan Ford and her colleagues set off our special issue with their article "Depression and Financial Distress in a Clinical Population: The Value of Interdisciplinary Services and Trainings". This article provides insight on what holistic care that addresses finances, mental health, and relational health look like in the real world. The setting of this paper is at the interdisciplinary Aspire Clinic at the University of Georgia where couple and family therapy and financial planning students work with clients together in client sessions. The article provides statistical evidence and anecdotal stories that highlight the need for mental health professionals to address underlying financial stress. 
The next two articles in this special issue take a deeper dive into financial stress and anxiety. First, Grable and colleagues explore "The Moderating Effect of Generalized Anxiety and Financial Knowledge on Financial Management Behavior". The authors connect the findings of their study to the need for financial therapy, which practitioners need to decrease anxiety and increase financial literacy to improve client outcomes. Ken White continues the examination of financial stress in his article entitled "Financial Stress and the Relative Income Hypothesis among Black College Students." As the title suggests, Dr. White examines financial stress in the special population of black college students. He finds that the phenomenon of "keeping up with the Joneses" leads to higher levels of stress in black students. There is a clear implication from his study that mental health professionals can aid our clients by examining how often they make peer comparisons and if they are experiencing any stress or anxiety from these false comparisons. His article also serves as an important reminder to ensure our research does not focus solely on white participants. The wealth gap in the United States continues to grow (Sullivan et al. 2015) and research is needed on how to improve the financial health of all Americans.

College is such a time of self-discovery, and this is true for discoveries around our relationship with money. Ken White examined black college students in his article and we stay with this population as we move into Butterbaugh, Ross, and Cambell's article, "My Money and Me: Attaining Financial Independence in Emerging Adulthood Through a Conceptual Model of Identity Capital Theory." This article explores the aspects of financial health and independence in emerging adulthood. The authors created a conceptual model that can aid practitioners in working with clients in this developmental stage.

Next, Jeanfreau, Holden, and Brazeal explore one of the most interesting aspects of financial therapy, financial infidelity, in their article called "Our Money, My Secrets: Why Married Individuals Commit Financial Infidelity". Using a mixed-method design of qualitative and qualitative data, the authors explore the reasons why married individuals commit financial infidelity in their relationship. One key takeaway from this article was how important it was for marriage and family therapists to address health communication practices around money in relationships.

The next three articles in this issue focus on different ways practitioners can do financial therapy. In the second article Megan Ford, Bruce Ross, John Grable, and Alycia De Graff continue to describe the work of the Aspire Clinic through in their article "Examining the Role of Financial Therapy on Relationship Outcomes and Help-Seeking Behavior." The article describes a three-session model involving a collaborative approach to financial therapy. Their findings highlight some of the benefits to financial therapy, including a surprising finding involving gender in help-seeking behaviors. Next Archuleta, Mielitz, Wayne and Le describe Solution Focused Financial Therapy. Using a quasi-experimental approach, they describe how to use Solution Focused Brief Therapy to decrease financial anxiety and relate that to mental health practices. Closing out this section, Nathan Astle and Emily Kooshel explore how Bowenian theory can be applied to a couple's financial conflict by balancing the need for privacy versus secrecy.

This special issue closes with Jerry Gale and colleagues arguing for the benefits of integrating financial therapy work into your mental health practice in their article, "Considerations, Benefits and Cautions Integrating Systems Theory with Financial Therapy." This article also highlights the benefits of integrating financial counseling tools with systems therapy. However, it also adds to the conversation by providing a look at the potential ethical and conceptual issues that could arise from cross-disciplinary collaborations. I truly enjoyed their recommendations for practitioners towards the end of the article, as it provides tangible footholds for practitioners getting started in this arena.

I hope this issue is another one of Dew's (2010) watershed moments for many of you couple and family therapists. I hope it emboldens you to take steps to work on both yours and your clients' financial health, as this issue will again draw attention to money's impact on our overall wellbeing.

\section{References}

Britt, S. L., Klontz, B. T., Tibbetts, R., \& Leitz, L. (2015). The financial health of mental health professionals. Journal of Financial Therapy, 6(1), 3. https://doi.org/10.4148/1944-9771.1076.

Dew, J. (2010). A note from the guest coordinator. Family Relations, 59(4), 341-342. https://doi.org/10.1111/j.1741-3729.2010.00606 .x.

Dew, J. P., \& Stewart, R. (2012). A financial issue, a relationship issue, or both? Examining the predictors of marital financial conflict. Journal of Financial Therapy, 3(1), 4. https://doi.org/10.4148/ jft.v3i1.1605.

FTA. (n.d.). Financial therapy. Retrieved from https://www.financialt herapyassociation.org/.

Glenn, C. E., Caulfield, B., McCoy, M., Curtis, J., Gale, N. C., \& Astle, N. (2020). An annotated bibliography of financial therapy research: 2010 to 2018. Journal of Financial Therapy. https://doi. org/10.4148/jft.v1i1.243.

Grable, J., McGill, S., \& Britt, S. (2010). The financial therapy association: A brief history. Journal of Financial Therapy, 1(1), 1. https ://doi.org/10.4148/jft.v1i1.235.

Klontz, B. T., Bivens, A., Klontz, P. T., Wada, J., \& Kahler, R. (2008). The treatment of disordered money behaviors: Results of an open clinical trial. Psychological Services, 5(3), 295-308. https://doi. org/10.1037/1541-1559.5.3.295.

Klontz, B. T., \& Britt, S. L. (2012). How clients' money scripts predict their financial behaviors. Journal of Financial Planning, 25(11), 33-43. 
Lee, C. Y. S., Lee, J., \& August, G. J. (2011). Financial stress, parental depressive symptoms, parenting practices, and children's externalizing problem behaviors: Underlying processes. Family Relations, 60(4), 476-490. https://doi.org/10.1111/j.1741-3729.2011.00656 .X.

Monger, J. (1998). The gap between theory and practice: A consideration of the fee. Psychodynamic Counselling, 4(1), 93-106. https ://doi.org/10.1080/13533339808404171.

Selenko, E., \& Batinic, B. (2011). Beyond debt. A moderator analysis of the relationship between perceived financial strain and mental health. Social Science \& Medicine, 73(12), 1725-1732. https:// doi.org/10.1016/j.socscimed.2011.09.022.

Sullivan, L., Meschede, T., Dietrich, L., \& Shapiro, T. (2015). The racial wealth gap. Waltham, MA: Institute for Assets and Social Policy, Brandeis University and DEMOS.
Sweet, E., Nandi, A., Adam, E. K., \& McDade, T. W. (2013). The high price of debt: Household financial debt and its impact on mental and physical health. Social Science \& Medicine, 91, 94-100. https ://doi.org/10.1016/j.socscimed.2011.09.022.

Publisher's Note Springer Nature remains neutral with regard to jurisdictional claims in published maps and institutional affiliations. 